\title{
An investigation into the challenges facing the planning of manpower
}

\author{
Ogunode Niyi Jacob ${ }^{1}$ \\ ${ }^{1}$ Federal University Wukari, Nigeria \\ Email:Ogunodejacob@gmail.com
}

\begin{abstract}
The study investigated the challenges facing the planning of manpower in the educational institutions in F.C.T, Abuja, Nigeria. We used survey research design for this study. Questionnaire was adopted for this study. The questionnaire was tagged "Investigate the challenges facing the planning of manpower in the educational institutions Questionnaire" The reliability of the instrument was determined through the use of test and re-test method. 80 educational planners and educational officers in charge of manpower planning in the ministry, department and agency of education were selected for the study through the use of purposive sampling method. Seven hypotheses were formulated by the researchers for the study. Mean, simple percentage and chi-square was used to analyze the information collected from the study. Data collected for the purpose of this study was collated, analyzed and the following was drawn that inadequate data/information, shortage of professional planners in manpower, inadequate working materials, poor capacity development of educational planners, political instability, lack of political and inadequate planning funds are the challenges facing the planning of manpower in the educational sector in F.C.T, Abuja.
\end{abstract}

Keywords: Challenges, Planning, Manpower.

\section{INTRODUCTION}

The Nigerian educational system consists the early child education between the age of 3 to 5 , the basic education 6 to 12, the secondary school education between age 12 to 18 and the higher education. The Nigerian educational system is the largest in Africa and it has the largest enrollment.

Nigeria's vision of education as an instrument for national development is reflected in the National Policy on Education, which states that "no nation can rise above the quality of its education system." The Government relies on education as a springboard for its development and reform agenda. Thus, five main national objectives have been endorsed as the necessary foundation for the National Policy on Education:

1) To build a free and democratic society;

2) To build a just and egalitarian society;

3) To build a united, strong and self-reliant nation;

4) To build a great and dynamic economy;

5) To build a land of bright and full opportunities for all citizens.

Planning of education is handled by the federal, states and local government. The federal government handles the planning of all federal college education and higher institutions and make policy direction for the basic education. The State government plan the secondary schools education and higher education within their domain while the local government coordinate and manage the basic education with the assistance from the national universal basic commission an agency of federal government.

Education planning is a broad field and very important for educational development of a country.

Education planning covers the following areas: Financial planning in education, Facilities planning, forecasting, projection, academic planning, plant planning, curriculum planning and Manpower planning. According to Noun (2012) the following informed the need for a systematic manpower planning in Nigeria:

a) Unemployment problem of the school leavers: 
b) In the early $1960 \mathrm{~s}$, the country experienced a serious drift in the large number of youths from the rural areas to the urban areas in search of wage employment. This massive drift led to serious unemployment of school leavers.

c) The need to provide skilled manpower for the expanding economy and to gear the educational system to meet the need.

d) The economy was expanding and the available manpower was grossly inadequate for development programmes. It was again very difficult to recruit adequate number of skills (specialists) required for the economy and to replace the expatriate staff who were leaving in droves. This is also because they were not available.

e) The World Bank Report of 1955 advocating for the need to increase, as speedily as possible, the number of adequately trained Nigerians who would be able to contribute effectively to economic growth. This was an indication of inadequate indigenous manpower needs in the country.

f) There was largely an occurrence of surplus unskilled labour and shortage of skilled labour in Nigeria resulting in an imperfect labour market situation.

g) Recognition by some advanced nations like U.S. that manpower was a basic resource which was then an indispensable means of converting other resources to the use and benefit of mankind.

Manpower planning in Nigeria have not been given maximum administration and this is causing many lapses in almost all the federal, states and local government ministries, agencies and educational institutions. Many educational institutions in Nigeria are either over staffed or under staffed. Tribune (2019) observes that there is currently a shortage of about 277,537 teachers in basic education schools in Nigeria, a new National Personnel Audit report has indicated. According to the report, there was a deficit of 135,319 teachers at the Early Childhood Care Development Education, 139,772 deficit in primary schools and 2,446 shortage in Junior Secondary Schools across the nation.

Abuja, the Federal Capital Territory of Nigeria is a home to many educational institutions. There are many challenges facing the various educational institutions in the City. One of the major challenge is the problem of manpower shortage. According to Guardian (2019) The Federal Capital Territory (FCT) Education Board has identified shortage of specialised teachers, classroom congestion and poor funding as major challenges facing both primary and secondary schools in the territory. The shortage of professional teachers in FCT can be linked to many reasons and one of the strong reason is the poor manpower planning for the educational institutions. The inability of manpower planners to plan the manpower for the educational institutions well is due to many challenges. This study is aimed to investigate the challenges facing manpower planning in educational institutions in FCT, Nigeria.

\section{STATEMENT OF THE PROGRAMME}

One of the greastest challenges facing the educational institutions in Nigeria is how to achieve manpower effectiveness and efficiency. Research has it that most educational institutions in Nigeria are either understaffed or over staffed. Anyadike (2013) cited Goetz, (1989) who submits that inadequacy of Human Resources Planning has been cited as the reason why most public organization today are facing a chaotic situations as they did not at onset plan their workforce, neither did have any systematic human resource (HR) management programme that put the organizations goals first and the decay in the public organizations is evident as the level of frustration is equally high; and the "marketplace" trend of organization is becoming a reality. The cause of this unfortunate development is primarily a lack of human resource planning. The Federal Capital Territory (FCT) Education Board has identified shortage of specialised teachers, classroom congestion and poor funding as major challenges facing both primary and secondary schools in the territory. Based on this submission, this study seek to investigate challenges facing manpower planning in educational institutions in FCT, Abuja, Nigeria.

\section{RESEARCH OBJECTIVES}

The aim of this study is to investigate the challenges facing the planning of manpower in the educational institutions in F.C.T, Abuja, Nigeria. Specific objectives are to:

1. To find out if inadequate data/information is a challenge facing the planning of manpower in the educational sector in F.C.T, Abuja, 
2. To find out if shortage of professional planners in manpower is a challenge facing the planning of manpower in the educational sector in F.C.T, Abuja.

3. To find out if inadequate working materials is a challenge facing the planning of manpower in the educational sector in F.C.T, Abuja.

4. To find out if poor capacity development of educational planners is a challenge facing the planning of manpower in the educational sector in F.C.T, Abuja.

5. To find out if political instability is a challenge facing the planning of manpower in the educational sector in F.C.T, Abuja.

6. To find out if lack of political is a challenge facing the planning of manpower in the educational sector in F.C.T, Abuja.

7. To find out if inadequate planning funds is a challenge facing the planning of manpower in the educational sector in F.C.T, Abuja.

\section{RESEARCH HYPOTHESES}

Based on the research questions raised, one hypotheses to test the hypotheses:

1) H0: There is no significant relationship between inadequate data/information and challenge facing the planning of manpower in the educational sector in F.C.T, Abuja,

2) H0: There is no significant relationship between shortage of professional planners in manpower and challenge facing the planning of manpower in the educational sector in F.C.T, Abuja.

3) H0: There is no significant relationship between inadequate working materials and challenge facing the planning of manpower in the educational sector in F.C.T, Abuja.

4) H0: There is no significant relationship between poor capacity development of educational planners and challenge facing the planning of manpower in the educational sector in F.C.T, Abuja.

5) H0: There is no significant relationship between political instability and challenge facing the planning of manpower in the educational sector in F.C.T, Abuja.

6) H0: There is no significant relationship between lack of political and challenge facing the planning of manpower in the educational sector in F.C.T, Abuja.

7) H0: There is no significant relationship between inadequate planning funds and challenge facing the planning of manpower in the educational sector in F.C.T, Abuja.

\section{LITERATURE REVIEW}

\section{Concept of Manpower Planning}

The concept of manpower planning takes various forms. There are various definitions by different authors. The concept of manpower planning is made of two words "Manpower" and "Planning" The two words mean different things but they are used together. Ojo (1986) observes that human capital is synonymous with manpower and means more than population or labour, manpower "is the managerial, scientific, engineering, technical, craftsman and other skills which are employed in creating, designing, developing organisations, managing and operating productive and service enterprises and economic organisations.

Manpower also known as human capital refers to human beings that possesses skills and knowledge to add value to the social and economic development of the society. Manpower can also be seen as the total number of men and women that have the qualification and skills to work and add value to the development of the country.

According to (Noun, 2012) Manpower on its own came into being through the formation of 'human capital'. Human capital concept relates to the provision of a skilled labour force that has gone through educational training. It involves the training of the educated citizens in the acquisition of specific skills that will enable them to function in the society. Human capital is the total number of human resources expertise available that can be used for production of goods and services in a country.

Garba (2000) views human capital as the total stock of human resources produced by a country from which it can pool skills (know-how), knowledge (know-what), entrepreneurial and innovative capacities required to produce, distribute and utilize ideas, goods and services to generate growth and development. 
Planning is the act of outlining the future actions with means of achieving them. Planning is the process of drawing out goals and objectives and deciding how to realize them within a time frame. Planning is the act of determining the tomorrow activities, programme and action from todays' schedule. Planning is the process of visualizing the future actions and identifying resources to use for achieving them. Planning is a process and an act that critically draw actions and activities for an intending projects and means to actualize the projects or programmes.

Manpower planning is a systematic planning that deals with how to replace the outgoing manpower in the local government, States and in the country. It is the strategic ways of deciding and providing manpower replacement in the country in every sector of the economy. (Noun, 2012) defines Manpower planning as an attempt to forecast the future demand for educated manpower. It leads to the acquisition of skills needed for the economy. In other words, the skill acquired by a person enables him to do certain things (for example, to teach, to construct a building, to repair engines, to sow, to drive, etc). The skills acquired by people thus turned them to become important 'human resources'. Manpower planning thus implies an attempt to integrate economic development and educational planning. It is a conscious attempt by the government to link the development of their educational systems to the demand for educated manpower by their economies.

Manpower planning means an act or process of making a systematic arrangement to fill up the manpower gap as they are unfolding in the country on every sector of the economy. Manpower planning deals with actions and programmes designed to prevent manpower shortage in the future.

Manpower planning is vital for the sustainability of the economy. It is life-wire of the country's human resources replacement document and actions.

Yesufu (2000) defines manpower planning simply as "the process of determining and effecting a balance between the available or potential human resources of a nation and their effective disposition and utilization". He thus viewed human resources as all embracing, inclusive of all who work now or are likely to be productively employed sooner or later while Ojo (1986) sees manpower planning as "the process of determining the policies and programmes that will develop, utilize and distribute manpower with a view to achieving a country's broader aims of socio economic and political development".

(Noun, 2012) submits that in modern economy, where demands for some skills become surplus while others are scarce. This is to say that at a point in time, there are surpluses of certain type of manpower in search of employment while at the same time, there are shortages of others which are in demand. In economic parlance, this situation makes the manpower market 'imperfect'. For the proper development of the economy, all available resources, especially 'human resources', must be properly coordinated and utilized. This is what manpower planning emphasizes.

According to Ojo (1986) manpower planning is intending to achieve the following:

a) identify the requirements for manpower for various sectors of the economy;

b) planning of formal education, on-the-job training, in-service programmes and adult education so as to provide required skills;

c) analysing the structure of incentives and the utilization of manpower, including unemployment and underemployment and appropriate measures for alleviating them;

d) developing the necessary organizations and institutions to be responsible for the execution of manpower programmes, and;

e) developing management and labour techniques, working conditions and industrial relations in order to ensure maximum productivity.

Reasons for Manpower planning in Education

1) to ensure sustainability in manpower availability in the educational institutions

2) to emilimate manpower wastages in the educational institutions

3) to ensure constant supply of manpower in the educational institutions

4) to ensure the educational institutions have adequate professions in all aspects of education industries

5) to ensure human capital development in the education industries.

The following are the important of manpower planning in the educational industries:

1) Manpower planning in education helps to prevent shortage of manpower in the sector 
2) Manpower planning in education helps to prevent educational wastages

3) Manpower planning in education helps to identify manpower needs in the educational sector and identify means of providing the needs

4) Manpower planning in education helps to actualize the goals of educational institutions

5) Manpower planning in education helps to

There are few research publication on this area of study among such study is that of Igbokwe-Ibeto, Osakede, \& Anazodo (2017) who examined effects of manpower planning and development in Lagos state civil service performance. Lagos state civil service is the greatest asset of the state in its quest for socio-economic development. The primary question that was explored is whether the nature of manpower planning and development curriculum in Lagos state civil service has effect on the service performance and the attainment of state objective. The study relied on primary and secondary data, and multiple stage sampling technique was used to select the sample population. The data collected was presented in frequency bar chart and simple percentage. Pearson's Product Moment Correlation Coefficient (PPMC) statistical tool was used to test the hypotheses. Findings of the study show that the nature of manpower planning and development curriculum has a positive effect on the Lagos state civil performance. It also reveals that the manpower planning and development has a positive effect on the attainment of Lagos state objective. To achieve better performance in the service, it should among others, improve on the current manpower planning strategy and continue to update its manpower development curriculum in line with the global best practices. Given the pivotal role that technology plays in the 21 st century, the service should avail itself the windows of opportunities that information technology provides in its drive to enhance employees' skills, knowledge and abilities that will invariably improve the service performance. Yet, the service should imbibe the prescripts of New Public Management theory (NPM), and that goals and targets should be defined and measurable as indicators of organizational performance.

Hamza (2012) did a study therefore seeks to examine the challenges of manpower planning in an organization using a case study of Obajana Cement Plc (OCP). In conducting the research work, personal interviews and questionnaires were used in data collection and data analysis was a simple percentage method. The questionnaire was administered randomly to a sample of 100 staff from the various departments of the company, of which 76 were filled and dully returned. Literature relevant to the study were extensively reviewed, and possible solutions were proffered. This research work is important since workers performance directly or indirectly depends on how well an organization plans its manpower. A major finding discovered in the course of carrying out this research work is that though OCP have the ideal personnel to employ manpower planning technique, it is still faced with the problem of planning its manpower. From the findings of the research, the following recommendations were made: Every organization should endeavor to give manpower planning the attention it desires. Experts in the area of manpower planning should be employed in companies/organizations to handle this complex assignment so that the aim of an effective manpower planning can be reaped by such organizations.

Anyadike, (2013) the following are some of the barriers of human resource planning in achieving employee productivity:

[1] Absence of productivity-oriented working culture and mechanisms to encourage labour productivity

[2] High cost of skilled labour, and training.

[3] The low level of computer literacy couple with the unstable power supply in this era of computer-based organization structuring, hence without strong information base, human resource planning becomes a tortuous assignment.

[4] Lack of the willingness to recognize special talents in the formal education systems and to encourage their development in specialized environments.

[5] Poor record keeping constraining human resource planning; even though human resource planning is not necessarily numerical estimation or list forecasting of the workforce, record keeping is the hub of human resource planning.

[6] Career guidance is not a mandatory element before the students leave schools after secondary education.

[7] Limitations in the available systems for accreditation of training institutions, preventing the training programmes on offer to meet job market needs and international standards. 
According to the same World Bank report in 2000, some of the major issues in Nigeria's teacher education that need attention are as follows:

(1) There is a shortage of primary school teachers needed to attain the proposed 1:30 (1:40 in the transition years) teacher-to-pupil ratio. This ratio is far from being met as the current ratio is 1:76.

(2) The low number of graduates going into the teaching profession is of grave concern. The major factors are the inadequate funding levels and low salaries. The fact is that teachers have become marginalized and the profession is the most impoverished of all sectors of the labour force in Nigeria. In almost every area of the system, conditions of the work environment, access to information, resources needed for supplies and equipment, salaries and benefits are extremely poor. Access to new technologies is virtually non-existent.

(3) Teacher quality throughout the 36 states in Nigeria is unequal. There are also inequities in the availability of qualified teachers in different states.

(4)Most primary school teachers at present are yet to attain the minimum qualification (i.e. the NCE) as required by the National Policy on Education.

(5) Most colleges of education offer courses which are neither appropriate nor relevant to the level and needs of most primary teachers. Teacher trainees in the colleges largely receive an education that is suited more for the junior secondary level than the primary level. The courses are largely of an academic nature as opposed to the development of processes, skills and career geared towards the primary school.

(6) There is an oversupply of the NCE-qualified and graduate teachers in some disciplines and subject combinations, while there is a general shortage of teachers in physics, mathematics, home economics, business education, technical education, primary education studies, nursery education and computer science.

(7) Leadership in colleges needs to be streamlined by the NCCE. Not all colleges are led by professionally qualified and competent staff with at least a higher degree in education.

(8) The serious gender imbalance in some states is of concern, particularly the decline in the number of male teachers and their importance as role models.

According to NEEDS (2014) the education sector in Nigeria have indicated that the primary and secondary subsectors also experience the problem of teacher shortage. Addressing the shortfall in the number of available teachers at the basic education level, the Executive Secretary of the NCCE disclosed that Nigeria needed 1,320,135 teachers to meet the demands of basic education by 2015 . To this end, the nation needed to produce a total of 330,033 teachers annually in order to achieve the EFA goal by 2015 (Junaid, 2013).

Research findings have also shown that Nigerian teachers are almost always in short supply in schools, and their turnover is high because they tend to leave the teaching profession if and when more attractive jobs become available in government, politics or private enterprises (NEEDS,2014, Aghenta, 2001; Adeyemi, 2008).

NEEDS (2014) discloses some facts about the composition of personnel in the education sector. As shown in the table, there is more support or non-teaching staff than lecturers in the tertiary education subsector. However, in the basic education subsector, the teaching staff tend to outnumber the nonteaching staff. The composition of personnel with regard to gender distribution shows significant gender disparities in favour of male staff at all levels of education. In basic education, 53.8 per cent and 51.8.2 per cent of available staff in primary and junior secondary schools, respectively, are male teachers. Gender disparities in favour of male teachers are more pronounced in tertiary education, as only 24 per cent and 17 per cent of lecturers in colleges of education and universities, respectively, are female teachers.

NEEDS (2014) Shortage of qualified teachers in Nigerian universities is well articulated in the reports of the Federal Government's needs assessment of Nigerian public universities carried out in 2012. According to the reports, only about 43 per cent of university lecturers have PhD qualifications. The remaining 57 per cent have qualifications below $\mathrm{PhD}$. Only seven universities have up to 60 per cent of their teaching staff with $\mathrm{PhD}$ qualifications. There are universities with fewer than five professors. For instance, the Kano State University of Science and Technology, Wudil, established 11 years ago and has 
been turning out graduates, has only one teaching staff with a professor ranking and 25 lecturers who are PhD degree holders. Similarly, the Kebbi State University of Science and Technology, established in 2006, has only two teaching staff in the professor category and five lecturers who have PhD qualifications.

The understaffing of universities in Nigeria has serious implications for quality instruction and academic productivity in the institutions. The situation has led to an increasing culture of visiting lecturership in the system. The few available qualified lecturers are recycled as visiting, adjunct, sabbatical and contract lecturers to work in many universities at the same time. Many of them are always on the road travelling from one university town to another and unable to meet their primary obligations with their tenureemployer (NEEDS 2014, Federal Ministry of Education, 2012).

Anyadike (2013) cited Goetz, (1989) who submits that inadequacy of Human Resources Planning has been cited as the reason why most public organization today are facing a chaotic situations as they did not at onset plan their workforce, neither did have any systematic human resource (HR) management programme that put the organizations goals first and the decay in the public organizations is evident as the level of frustration is equally high; and the "marketplace" trend of organization is becoming a reality. The cause of this unfortunate development is primarily a lack of human resource planning.

From the above literature reviewed, it is obvious that there is a research gap in the area of challenges facing planning of manpower in the educational institutions in FCT, Abuja, Nigeria. Based on this research gap, this study is aimed to investigate the challenges facing the planning of manpower in the educational institutions in F.C.T, Abuja, Nigeria.

\section{METHODOLOGY}

The objective of this study is to investigate the challenges facing the planning of manpower in the educational institutions in F.C.T, Abuja, Nigeria. Survey research design for this study. Questionnaire was adopted for this study. The questionnaire was tagged "Investigate the challenges facing the planning of manpower in the educational institutions Questionnaire" The questionnaire was designed by the researcher with the assistance of two lecturers from University of Abuja who verified the questionnaire. The questionnaire had two section. Section A and B. Section A collected information on bio-data of respondents while section B collected information on the subject matter. The questionnaire employed four liker scale rating: Strongly Agree-4, Agree-3, Strongly Disagree-2 and Disagrr-1. The questionnaire was an open structure questionnaire. The questionnaire contained twenty one sub-item questions. The reliability of the instrument was determined through the use of test and re-test method. Twenty sample of the questionnaires were administered to educational planners in Kogi state a nearby state that share similar attribute with place of research. The questionnaires were given to them two times after weeks. The result collected showed 0.76 which was okay for the instrument to be used for the research at hand. 80 educational planners and educational officers in charge of manpower planning in the ministry, department and agency of education were selected for the study through the use of purposive sampling method. Seven hypotheses were formulated by the researchers for the study. The questionnaire was distributed to the respondents through the assistance of a research helper who went to the offices of the respondent one after the others. All questionnaire given out were collected for the study. Mean, simple percentage and chi-square was used to analyze the information collected from the study.

\section{RESULT ANALYSIS}

1. H0: There is no significant relationship between inadequate data/information and challenge facing the planning of manpower in the educational sector in F.C.T, Abuja.

Table 1

\begin{tabular}{|l|l|l|l|l|l|}
\hline Variable & N & Df & r-cal & t-table & Result \\
\hline $\mathrm{X}$ & & $\mathbf{8 0}$ & & & \\
\hline & & $\mathbf{7 8}$ & $\mathbf{0 . 2 5 4}$ & $\mathbf{0 . 1 9 5}$ & Significant \\
\hline
\end{tabular}

The result collected from table one showed that the Calculated Value 0.254 is greater than the Table Value (0.195).

2. H0: There is no significant relationship between shortage of professional planners in manpower and challenge facing the planning of manpower in the educational sector in F.C.T, Abuja..

Table 2 


\begin{tabular}{|l|l|l|l|l|l|}
\hline Variable & N & Df & r-cal & t-table & Result \\
\hline $\mathrm{X}$ & & $\mathbf{2 0 0}$ & & & \\
\hline & & $\mathbf{1 9 8}$ & $\mathbf{0 . 2 6 1}$ & $\mathbf{0 . 1 9 5}$ & Significant \\
\hline
\end{tabular}

The result collected from table two showed that the Calculated Value 0.261 is greater than the Table Value (0.195).

3. H0: There is no significant relationship between inadequate working materials and challenge facing the planning of manpower in the educational sector in F.C.T, Abuja.

Table 3

\begin{tabular}{|l|l|l|l|l|l|}
\hline Variable & N & Df & r-cal & t-table & Result \\
\hline$X$ & & $\mathbf{8 0}$ & & & \\
\hline & & $\mathbf{7 8}$ & $\mathbf{0 . 2 5 6}$ & $\mathbf{0 . 1 9 5}$ & Significant \\
\hline
\end{tabular}

The result collected from table three showed that the Calculated Value 0.256 is greater than the Table Value (0.195).

4. H0: There is no significant relationship between poor capacity development of educational planners and challenge facing the planning of manpower in the educational sector in F.C.T, Abuja.

Table 4

\begin{tabular}{|l|l|l|l|l|l|}
\hline Variable & N & Df & r-cal & t-table & Result \\
\hline $\mathrm{X}$ & & $\mathbf{8 0}$ & & & \\
\hline & & $\mathbf{7 8}$ & $\mathbf{0 . 2 6 8}$ & $\mathbf{0 . 1 9 5}$ & Significant \\
\hline
\end{tabular}

The result collected from table from showed that the Calculated Value 0.268 is greater than the Table Value (0.195).

5. H0: There is no significant relationship between political instability and challenge facing the planning of manpower in the educational sector in F.C.T, Abuja.

Table 5

\begin{tabular}{|l|l|l|l|l|l|}
\hline Variable & N & Df & r-cal & t-table & Result \\
\hline $\mathrm{X}$ & & $\mathbf{8 0}$ & & & \\
\hline & & $\mathbf{7 8}$ & 0.271 & $\mathbf{0 . 1 9 5}$ & Significant \\
\hline
\end{tabular}

The result collected from table five showed that the Calculated Value 0.271 is greater than the Table Value (0.195).

6. H0: There is no significant relationship between lack of political and challenge facing the planning of manpower in the educational sector in F.C.T, Abuja.

Table 6

\begin{tabular}{|l|l|l|l|l|l|}
\hline Variable & N & Df & r-cal & t-table & Result \\
\hline$X$ & & $\mathbf{8 0}$ & & & \\
\hline & & $\mathbf{7 8}$ & 0.277 & $\mathbf{0 . 1 9 5}$ & Significant \\
\hline
\end{tabular}

The result collected from table five showed that the Calculated Value 0.277 is greater than the Table Value (0.195).

7. H0: There is no significant relationship between inadequate planning funds and challenge facing the planning of manpower in the educational sector in F.C.T, Abuja.

Table 7

\begin{tabular}{|l|l|l|l|l|l|}
\hline Variable & N & Df & r-cal & t-table & Result \\
\hline $\mathrm{X}$ & & $\mathbf{8 0}$ & & & \\
\hline & & $\mathbf{7 8}$ & 0.281 & $\mathbf{0 . 1 9 5}$ & Significant \\
\hline
\end{tabular}

The result collected from table five showed that the Calculated Value 0.281 is greater than the Table Value (0.195).

\section{RESULT DISCUSSION}

To find out if inadequate data/information is a challenge facing the planning of manpower in the educational sector in F.C.T, Abuja,

Reaction of the respondents on this research question revealed that the Calculated Value 0.254 is greater than the Table Value (0.195). Therefore, the Alternate hypothesis (Hi) was accepted, while the null hypothesis (Ho) was rejected. This means there is significant relationship between inadequate 
data/information and challenge facing the planning of manpower in the educational sector in F.C.T, Abuja. This result is in support of Ogunode (2014) conclusion that inadequate data/information is one of the major challenge facing the planning of manpower in Nigeria.

To find out if shortage of professional planners in manpower is a challenge facing the planning of manpower in the educational sector in F.C.T, Abuja.

Responses to the research question two showed that the Calculated Value 0.261 is more than the Table Value (0.195). Therefore, the Alternate hypothesis (Hi) was accepted, while the null hypothesis (Ho) was rejected. This implies that there is significant relationship between shortage of professional planners in manpower and challenge facing the planning of manpower in the educational sector in F.C.T, Abuja. Effective planning of manpower is only possible when there are professional manpower planners available in quantity. The shortage of manpower planners in Nigeria is one of the factor responsible for poor planning of manpower (Ogunode, 2014).

To find out if inadequate working materials is a challenge facing the planning of manpower in the educational sector in F.C.T, Abuja.

The result collected from table three showed that the Calculated Value 0.256 is greater than the Table Value (0.195). Therefore, the Alternate hypothesis (Hi) was accepted, while the null hypothesis (Ho) was rejected. There is significant relationship between inadequate working materials and challenge facing the planning of manpower in the educational sector in F.C.T, Abuja.

When the working environment is conducive people work well and when it is unconducive, people are unmotivated to work. The provision of conducive environment is very important to increase productivity. Ogunode (2014) found out that the working environment most planners find themselves today in Nigeria is not conducive to work.

To find out if poor capacity development of educational planners is a challenge facing the planning of manpower in the educational sector in F.C.T, Abuja.

Result obtained in regarding research question four disclosed that the Calculated Value 0.268 is more than the Table Value (0.195). Therefore, the Alternate hypothesis (Hi) was accepted, while the null hypothesis (Ho) was rejected. This means that there is significant relationship between poor capacity development of educational planners and challenge facing the planning of manpower in the educational sector in F.C.T, Abuja.

To find out if political instability is a challenge facing the planning of manpower in the educational sector in F.C.T, Abuja.

The result collected from table five showed that the Calculated Value 0.271 is greater than the Table Value (0.195). Therefore, the Alternate hypothesis (Hi) was accepted, while the null hypothesis (Ho) was rejected. There is significant relationship between political stability and challenge facing the planning of manpower in the educational sector in F.C.T, Abuja.

To find out if lack of political is a challenge facing the planning of manpower in the educational sector in F.C.T, Abuja.

Reaction to research question six showed that the Calculated Value 0.277 is greater than the Table Value (0.195). Therefore, the Alternate hypothesis (Hi) was accepted, while the null hypothesis (Ho) was rejected. There is significant relationship between lack of political and challenge facing the planning of manpower in the educational sector in F.C.T, Abuja. Political will is very important in achieving government policies and programme. The lack of political support for manpower planning is responsible for the manpower mismanagement in the country (Ogunode, 2014).

To find out if inadequate planning funds is a challenge facing the planning of manpower in the educational sector in F.C.T, Abuja.

Regarding research question seven, result collected revealed that the Calculated Value 0.281 is greater than the Table Value (0.195). Therefore, the Alternate hypothesis (Hi) was accepted, while the null hypothesis (Ho) was rejected. There is significant relationship between inadequate planning funds and challenge facing the planning of manpower in the educational sector in F.C.T, Abuja. This finding confirm the submission of Ogunode (2014) that one of the challenges facing the manpower planning in Nigeria is inadequate funds for planning. 


\section{CONCLUSION AND RECOMMENDATION}

Inadequate supply of professional teachers in the Nigerian educational sector is affecting the teaching quality. Almost all the Nigerian educational system have deficit of professional teachers. This problem is due to lack of comprehensive manpower planning in the educational sector. Planning of education in Nigeria and especially the planning of manpower for various educational system is always been faced with many challenges. Thus; this study was designed to investigate the challenges facing the planning of manpower in the educational sector in F.C.T, Abuja, Nigeria and the specific objectives of the study include to:

a. To find out if inadequate data/information is a challenge facing the planning of manpower in the educational sector in F.C.T, Abuja,

b. To find out if shortage of professional planners in manpower is a challenge facing the planning of manpower in the educational sector in F.C.T, Abuja.

c. To find out if inadequate working materials is a challenge facing the planning of manpower in the educational sector in F.C.T, Abuja.

d. To find out if poor capacity development of educational planners is a challenge facing the planning of manpower in the educational sector in F.C.T, Abuja.

e. To find out if political instability is a challenge facing the planning of manpower in the educational sector in F.C.T, Abuja.

f. To find out if lack of political is a challenge facing the planning of manpower in the educational sector in F.C.T, Abuja.

g. To find out if inadequate planning funds is a challenge facing the planning of manpower in the educational sector in F.C.T, Abuja.

By the end of the research, the result collected from the study led to the following conclusion that:

1. Inadequate data/information, is a challenge facing the planning of manpower in the educational sector in F.C.T, Abuja.

2. Shortage of professional planners in manpower is a challenge facing the planning of manpower in the educational sector in F.C.T, Abuja.

3. Inadequate working materials is a challenge facing the planning of manpower in the educational sector in F.C.T, Abuja.

4. Poor capacity development of educational planners is a challenge facing the planning of manpower in the educational sector in F.C.T, Abuja.

5. Political instability is a challenge facing the planning of manpower in the educational sector in F.C.T, Abuja.

6. Lack of political is a challenge facing the planning of manpower in the educational sector in F.C.T, Abuja.

7. Inadequate planning funds is a challenge facing the planning of manpower in the educational sector in F.C.T, Abuja.

Based on this result, the following were recommended:

1. The government should increase the fund of educational planning in FCT to enable more funds to carry out planning activities

2. The government should employ more professional planners with specialization in manpower planning, this will aid effective manpower planning in FCT and in Nigeria

3. Planning equipment should be bought and distribute to planners in working in the ministries

4. Training and retraining programme should constantly be organized for educational planners in the ministries and department of education to update their planning methods and skills

5. The government should ensure political stability and policies continuity in the ministry of education regarding planning programmes.

\section{REFERENCES}

1. Anyadike, N,. O.(2013). Human resource planning and employee productivity in nigeria public organization. Global Journal of Human Resource Management Vol.1, No .4, pp.56-68,

2. Federal Ministry of Education (FME) (2011) Digest of Educational Statistics. FME, Abuja.

3. Federal Ministry of Education (FME) (2012) Reports on Need Assessment of Nigerian Public Universities. FME, Abuja.

4. Garba, P.K. (2000). "Human Capital Formation, Utilization and the Development of Nigeria: A System Analysis" in 2002 Annual Conference of the Nigerian Econ. Society. 
5. Guardian (2019) Shortage of teachers, congestion, major challenges facing FCT schools, https://guardian.ng/news/shortage-of-teachers-congestion-major-challenges-facing-fct-schoolsmohammed/\#:

6. Goetz, B. E. (1989), Management Planning and Control. New York: McGraw Hill Book Company.

7. Hamza, I. (2012). Challenges of manpower planning in an organization: a case study of Obajana cement plc, Kogi State.

8. Igbokwe-Ibeto, Osakede, \& Anazodo, (2017). The Effect of Manpower Planning \& Development in Lagos State Civil Service Performance. Africa's Public Service Delivery \& Performance Review

9. Junaid, I.M. (2013) Education: Quality, standards and control in Nigeria transformation agenda. Lecture delivered at the 35th convocation ceremony of the Federal College of Education (Technical), Akoka, Lagos.

10. Noun (2012). Manpower approach in educational planning. Lagos

11. Ojo, F. (1986). "Nigeria's Manpower Planning Experience" In Ojo, F., Aderinto, A. and Fashoyin, T. (Eds) Manpower Development and Utilization in Nigeria: Problems and Policies. Lagos: Lagos Univ. Press. Pp 1-21.

12. Ogunode, N,J. (2014). Evaluation of Manpower Programme in Nigeria. Bex Publisher. P-12.

13. Sobanjo (2014). Manpower Development in Nigeria https://sobanjointernational.com/2014/07/10/manpower-development-in-nigeria/

14. Tribune (2019). Nigeria Has Shortage Of 277,537 Teachers In Basic Education Schools UBEC, https://tribuneonlineng.com/nigeria-has-shortage-of-277537-teachers-in- basiceducation-schools-\%E2\%80\%95-ubec/

15. Yesufu, T.M. (2000). The Human Factor in National Development: Nigeria. Benin/Ibadan: Spectrum Books Ltd and Univ. of Benin. 